Online first

e-ISSN 2544-090X

C www.catallaxy.pl



Oryginalny artykuł naukowy

otrzymano: 01.07.2019 / zaakceptowano: 02.09.2019 / opublikowano online: 16.09.2019

Jakubowska, M. (2019). Szara strefa w gospodarce i metody jej zwalczania w zakresie ograniczania skali nierejestrowanych transakcji. Catallaxy. 4(2): 87-94. doi:10.24136/cxy.2019.008.

\title{
Szara strefa w gospodarce i metody jej zwalczania w zakresie ograniczania skali nierejestrowanych transakcji
}

\author{
MARTA JAKUBOWSKA \\ Uniwersytet Mikotaja Kopernika w Toruniu, Wydział Nauk Ekonomicznych i Zarzadzania, Katedra Zarzadzania \\ Finansami, ul. Gagarina 13a, 87-100 Torú, Polska \\ $\square$ marta.jakubowska.umk@gmail.com \\ (D) orcid.org/0000-0001-9067-4524
}

\begin{abstract}
Abstrakt
Motywacja: Szara strefa ciągle pozostaje problemem niewystarczająco zbadanym, a mającym bardzo duży i negatywny wpływ na funkcjonowanie gospodarki. Stanowi problem nie tylko dla budzetu państw, ale także jedno z zagrożeń dla legalnie działających przedsiębiorstw.

Cel: Celem głównym artykułu jest identyfikacja szarej strefy z uwzględnieniem przyczyn jej rozwoju. Jako cel szczegółowy przyjęto wskazanie metod walki z szarą strefą w zakresie ograniczania skali nierejestrowanych transakcji.

Materiały i metody: W artykule wykorzystano analizę źródeł wtórnych, a także literatury przedmiotu. Wyniki: Na podstawie przeprowadzonej analizy można uznać, że problem istnienia szarej strefy w gospodarce jest ciągle aktualny. Jedną z metod walki z szarą strefą, szczególnie w obszarze skali nierejestrowanych transakcji, są działania promujące rozwój obrotu bezgotówkowego. Zwrócono także uwagę na możliwość blokowania rozwoju obrotu bezgotówkowego przez przedsiębiorstwa działające w szarej strefie. Problem ten wymaga jednak pogłębionych, kompleksowych badań w przyszłości.
\end{abstract}

Stowa kluczowe: szara strefa; transakcje nierejestrowane; obrót bezgotówkowy

JEL: O17; E62; E42

\section{Wprowadzenie}

Zjawisko szarej strefy jest problemem, z którym borykają się wszystkie państwa świata, a jego skutki odczuwalne są na wielu płaszczyznach życia społeczno-gospodarczego. Mimo podejmowania wielu inicjatyw prowadzących do jej redukcji, niezwykle trudno jest wypracować działania skutecznie ją zwalczające. W doniesieniach mediów temat szarej strefy jest często utożsamiany z pracą na czarno lub $z$ działaniem nielegalnym. Co więcej, często wywołuje ona skrajne odczucia społeczne od potępienia do przyzwolenia czy traktowania tego zjawiska jako działalności z różnych względów dopuszczalnej lub nawet właściwej. W pierwszej kolejności konieczna jest zatem odpowiedź na pytanie o to czym jest szara strefa.

Zjawisko szarej strefy jest w różny sposób definiowane w literaturze. Według F. Schneider i D.H. Enste (2000, ss. 77-114), pojęcie to oznacza „wszystkie aktywności gospodarcze przyczyniające się do oficjalnego (bądź 
też obserwowalnego) PKB, ale ciągle pozostające niezarejestrowane". Główny Urząd Statystyczny (2019) definiuję szarą strefę jako „działalność produkcyjną legalną, ale celowo ukrywaną przed władzami publicznymi w celu uniknięcia podatków lub ominięcia określonych przepisów". Pojęcie to określane jest również jako: gospodarka nieformalna, drugi obieg gospodarczy lub gospodarka w cieniu (shadow economy). W niniejszym artykule przyjęto określenie "szara strefa gospodarcza”, rozumiejąc przez to gospodarke nieobserwowaną, sformułowaną zgodnie $z$ zasadami Europejskiego Systemu Rachunków Narodowych i Regionalnych (European System of Accounts, ESA 2010). Na szarą strefę składają się trzy podstawowe elementy (Instytut Badań nad Gospodarką Rynkową, 2016, s. 6):

- działalność nielegalna, w której obie strony są dobrowolnymi partnerami transakcji gospodarczej;

- działalność ukryta, w przypadku której transakcje same $\mathrm{w}$ sobie nie są niezgodne z prawem, ale nie zostają zgłaszane w celu uniknięcia procedur lub kosztów administracyjnych;

- działalność określana jako „nieformalna”, występująca w sytuacji, gdy nie prowadzi się żadnej ewidencji.

Należy jednak wyraźnie podkreślić, że szara strefa nie mieści się $\mathrm{w}$ dualistycznym podziale: gospodarka legalna i nielegalna. Działania w szarej strefie nie są legalne ani wyłącznie nielegalne. "Gospodarka ukryta" przekracza granice legalności, ale w wielu przypadkach nie staje się zawsze nielegalna. Taka sytuacja wynika $z$ faktu, że między funkcjonowaniem szarej strefy a poszczególnymi sferami gospodarki oficjalnej występują zależności mające charakter sprzężeń zwrotnych (Instytut Koniunktur i Cen Handlu Zagranicznego, 2005, s. 30).

$\mathrm{Na}$ potrzeby niniejszej pracy, skoncentrowano się głównie na tej części szarej strefy, która dotyczy sprzedaży towarów i usług w ramach transakcji detalicznych. Natomiast aspekty związane $z$ drugim głównym obszarem szarej strefy, tj. nieoficjalnym zatrudnieniem, nazywanym téz "pracą na czarno”, stanowią tło dla prowadzonych rozważań badawczych. W związku z tym, w oparciu o przedstawione rozważania oraz przeprowadzone studia literatury, zaproponowano autorską definicję szarej strefy w obszarze nieoficjalnych transakcji, zgodnie z którą transakcje nierejestrowane są to transakcje sprzedaży produktów i usług na rzecz konsumentów, które nie są rejestrowane $z$ użyciem urządzenia fiskalnego lub innej, wymaganej prawem metody rejestracji, mimo istnienia obowiązku prawnego dla danego podmiotu.

Należy zwrócić uwagę, że dokonywanie tak zdefiniowanych "transakcji nierejestrowanych" skutkuje w szczególności obniżeniem obciążeń z tytułu podatku od towarów i usług (value-added tax, VAT) i dochodowego. Ponadto, może prowadzić do utraty praw przez konsumentów, którzy nie otrzymają paragonu potwierdzającego nabycie towaru lub usługi. Można wnioskować, że w związku z przytoczoną definicją, dużą rolę $w$ tym rozważaniu będzie odgrywał sposób płatności za transakcje $-z$ użyciem gotówki lub bezgotówkowych instrumentów płatniczych. Cechą płatności gotówkowej jest to, że fakt jej przekazania sprzedawcy nie podlega rejestracji $\mathrm{w}$ systemach elektronicznych. W przeciwieństwie do płatności bezgotówkowych takich, jak np. $z$ użyciem kat płatniczych, w przypadku których transakcja podlega rejestracji przez system bankowy. W rezultacie, nieuczciwy sprzedawca, który nie zarejestruje transakcji do celów fiskalnych, musi liczyć się z tym, że kontrola dokonywanych na jego rzecz płatności bezgotówkowych, może spowodować wykrycie takich transakcji przez służby skarbowe. $Z$ tego względu, podmioty prowadzące całość lub nawet cześć działalność w szarej strefie są zazwyczaj niechętne przyjmowaniu płatności w formie bezgotówkowej. Pozwala to przypuszczać, że przedsiębiorcy, którzy stosują proceder nierejestrowanych transakcji, nie będą skłonni do rozpoczęcia akceptacji kart płatniczych.

Ponadto, w przypadku transakcji nierejestrowanych szara strefa, może mieć charakter aktywny lub pasywny (Global Compact Network Poland, 2016, s. 5). Aktywna szara 
strefa (committed shadow economy) to taka, w której gotówka jest konsekwencją, np. usługa budowlana wykonana po obniżonej cenie, ale bez wystawienia faktury. W przypadku pasywnej szarej strefy (passive shadow economy), gotówka jest przyczyną, np. konsument płaci za usługę regularną cenę, ale paragon nie jest wystawiony.

Według badań przeprowadzonych przez Global Compact Network Poland (2016, s. 5), pasywna szara strefa stanowi około $86 \%$ szarej strefy, co wskazuje na znaczny potencjał jej ograniczenia przez promowanie płatności elektronicznych w transakcjach konsumenckich.

W sekcji 2. dokonano przeglądu literatury. W sekcji 3. opisano wykorzystane materiały i metody. W sekcji 4. przedstawiono otrzymane wyniki, natomiast w sekcji 5. zawarto podsumowanie przeprowadzonej analizy.

\section{Przegląd literatury}

Istnienie sektora gospodarki nieformalnej jest zjawiskiem co najmniej tak samo starym, jak instytucja samego państwa. Już Demokryt wskazywał na problem unikania opłat za korzystanie $z$ dóbr publicznych $\mathrm{w}$ starożytnej Grecji (Janik, 2010, s. 43).

\subsection{Przyczyny rozwoju szarej strefy}

Rozwój szarej strefy to wypadkowa wielu czynników. Według raportu Ministerstwa Pracy i Polityki Społecznej (2008), najważniejszymi czynnikami, które kształtują rozmiary szarej strefy są kwestie dotyczące podatków, kosztów zatrudniania i ogólnie przepisów prawa pracy oraz podaży siły roboczej. Z wysokimi kosztami zatrudnienia i skomplikowanymi przepisami łatwiej radzą sobie większe przedsiębiorstwa. W przypadku małych, można zaobserwować ucieczkę w szarą strefę. Największy wpływ na redukcję skali pracy nierejestrowanej miałoby ograniczenie kosztów pracy, w tym przede wszystkim składek na ubezpieczenia społeczne. Względna wysokość podatków od dochodów osobistych w Polsce, w porównaniu do innych państw, jest niewielka. Rekompensują to jednak bardzo wysokie obciążenia społeczne, przekraczające $38 \%$ wynagrodzenia brutto. Uproszczenie prawa pracy i redukcja formalności związanych $z$ zatrudnieniem nowego pracownika, to kolejne metody redukcji szarej strefy.

$Z$ kolei F. Schneider (2014, s. 4), za główne powody istnienia szarej strefy uznaje unikanie: - płacenia podatków od osób fizycznych i prawnych, VAT oraz innych podatków i opłat;

- płacenia obowiązkowych składek na ubezpieczenia społeczne;

- przestrzegania standardów rynku pracy takich, jak np. minimalnej płacy, standardów BHP;

- postępowania zgodnie $z$ określonymi procedurami administracyjnymi, np. wypełnianie statystycznych kwestionariuszy, obowiązkowe i czasochłonne odwiedzanie urzędów, składanie wypełnianych formularzy.

Istotnym czynnikiem, także sprzyjającym powstawaniu szarej strefy, jest $\mathrm{w}$ nieodpowiedni sposób prowadzona pomoc społeczna skutkująca uzależnieniem, i w konsekwencji zmniejszeniem, szans na zatrudnienie (Topolewska, 2010). Jeśli pomoc społeczna jest uzależniona od wysokości rejestrowanych dochodów z pracy, to osoby nią objęte same próbują uzyskać nielegalne zatrudnienie, aby nie wykazać dochodu służbom podatkowym. Przyczyny występowania szarej strefy można przedstawić w bardziej ogólnej klasyfikacji, w podziale na trzy grupy przyczyn występowania: ekonomiczne, instytucjonalne i psychologiczne.

Na przyczyny ekonomiczne składają się: całkowity brak dochodów lub dochody bardzo niskie niewystarczające do życia, brak podjęcia legalnej pracy z obawy przed utratą świadczeń w przypadku podpisania umowy o pracę (np. w przypadku emerytów i bezrobotnych). Z kolei druga grupa jest bezpośrednio związana $z$ wysokimi podatkami, nakładanymi na pracę, wysokimi zasiłkami dla bezrobotnych, a także regulacjami rynku pracy (łatwość zwalniania i zatrudniania). Czynniki psychologiczne to przede wszystkim moralność społeczna, 
która daje przyzwolenie na pracę na „czarno” lub skłonność do podejmowania ryzyka (Gołębiewski, 2007, s. 12).

\subsection{Wpływ regulacji prawnych na gospodarke nieformalną}

Liczba umów, licencji, zakazów pracowniczych, obowiązkowych koncesji, regulacji rynkowych czy zezwoleń potrzebnych do prowadzenia działalności gospodarczych i inne ograniczenia związane $z$ bezpieczeństwem, normami jakościowymi i technicznymi, prowadzą do wzrostu kosztów zarówno dla obywatela, pracownika, jak i pracodawcy. Stają się więc bodźcem do działania w szarej strefie (Schneider i Enste, 2000, ss.77-114). W Polsce $z$ roku na rok przybywa regulacji prawnych. Według badań prowadzonych przez przedsiębiorstwo Grant Thornton (2016), w 2014 roku wynosily one 25,6 tys. stron, a w 2015 roku liczba ta wzrosła do 29,8 tys. stron. Ponadto, Polska jest liderem $\mathrm{w}$ tworzeniu prawa w całej Unii Europejskiej (UE). W Polsce występuje aż pięćdziesiąt sześć razy więcej przepisów niż w Szwecji i kilkakrotnie więcej niż na Słowacji, w Czechach czy Wegrzech. To poważna bariera w rozwoju polskiej gospodarki. Dla porównania, w Polsce w 1992 roku regulacje zajmowały 1,8 tys. stron (Grant Thornton, 2016). Badania czołowych naukowców, w tym F. Schneider i Enste (2000, ss. 77-114), dowodzą, że im mniejsza przejrzystość prawa i narastająca liczba przepisów, tym bardziej zauważalna jest skłonność przedsiębiorców do unikania opodatkowania.

Podmioty działające w szarej strefie, przez unikanie płacenia podatków czy niezachowywanie norm jakościowych, stają się bardziej konkurencyjne od przedsiębiorstw rzetelnie wywiązujących się z podatków publicznych oraz $z$ innych obowiązków. W związku z tym, Ministerstwo Finansów w Polsce zainicjowało wprowadzenie regulacji prawnych, nastawionych bezpośrednio na zwalczanie szarej strefy w gospodarce, w szczególności w obszarze paliw, alkoholu, wyrobów tytoniowych i gier hazardowych (Najwyższa Izba Kontroli, 2017).
Opracowano także rozwiązania przyczyniające się do poprawy sytuacji w sposób pośredni, przez ograniczanie nieuczciwej konkurencji i stwarzanie lepszych warunków działalności dla uczciwych przedsiębiorców. Można zaliczyć do nich regulacje uszczelniające system podatkowy, mające na celu zwalczanie oszustw podatkowych i ograniczanie możliwości optymalizacyjnych. Podjęte, bądź zainicjowane, zmiany szczególnie dotyczyły: Ustawy o podatku akcyzowym, Ustaw o podatkach dochodowych, Ustawy o podatku od towarów i ustug, Ustawy Ordynacja podatkowa, Ustawy o swobodzie dziatalności gospodarczej, a także Kodeksu karnego skarbowego (Global Compact Network Poland, 2016, s. 65).

Po zakończeniu kontroli NIK, weszły w życie nowe regulacje:

- od 1 stycznia 2017 roku obowiązuje Pakiet uszczelniający VAT, a także obniżony limit dla transakcji gotówkowych. Co więcej kolejna grupa przedsiębiorców jest zobowiązana stosować regulacje o Jednolitym Pliku Kontrolnym (JPK);

- zmiany w Kodeksie karnym zaostrzające wymiar kar za wyłudzenia podatku VAT i wystawianie fałszywych faktur (nawet do 25 lat pozbawienia wolności) (Ustawa, 2017).

- 1 marca 2017 roku powołano Krajową Administrację Skarbową;

- od 1 kwietnia 2017 roku, a częściowo od 1 lipca 2017 roku, zaczęły obowiązywać zmiany w Ustawie o grach hazardowych, od 18 kwietnia 2017 roku obowiązuje pakiet przewozowy (Najwyższa Izba Kontroli, 2017).

- od 1 stycznia 2018 roku wprowadzono regulacji w zakresie kas fiskalnych online.

\subsection{Metody zwalczania szarej strefy}

Mimo występowania także pozytywnych skutków szarej strefy, nie należy zapominać o tym, $\dot{z}$ e te negatywne konsekwencje gospodarki nieobserwowalnej nie są równoważone przez pozytywne, bo $z$ reguly są one dużo poważniejsze i w niewielki sposób wpływają na PKB (Gołębiewski, 2007, s. 12). W związku z tym, 
priorytetowym wydaje się dążenie do uszczelnienia systemu podatkowego przez zmniejszenie szarej strefy, jaki i luki podatkowej.

W ocenie Instytutu Badań Nad Gospodarką Rynkową (2016, s. 5), wskazana jest polityka gospodarcza, w tym szczególnie polityka regulacyjna prowadząca do ograniczania zakresu działalności niezarejestrowanej. Ważnym przedsięwzięciem jest dążenie do obniżania podatków i upraszczanie systemu podatkowego, co z pewnością istotnie ograniczyłoby skłonność przedsiębiorstw do przechodzenia do szarej strefy.

Również wyższe kary za działalność ukrytą mogłyby w znaczący sposób wpłynąć na ograniczenie działalności $w$ gospodarce nieobserwowalnej (metoda represyjna). Niestety im niższa kara i wykrywalność tego typu aktywności, tym większe ryzyko istnienia szarej strefy (Instytut Prognoz i Analiz Gospodarczych, 2018). W Polsce w 2017 roku $\mathrm{w}$ znaczącym stopniu zaostrzono odpowiedzialność karną za wyłudzenia podatku VAT. Przy procederach przestępczych, gdy wartość towarów lub usług wskazanych w fałszywych fakturach przewyższać będzie $10 \mathrm{mln}$ PLN, sprawcom grozić będzie, tak jak w przypadku najpoważniejszych zbrodni, kara pozbawienia wolności w wymiarze od 5 do 15 lat, a w najcięższych wypadkach nawet 25 lat (Podatki. biz, 2017).

Warto także prowadzić działania zmierzające do ograniczania innych kosztów związanych $z$ działalnością gospodarczą, zmniejszać liczbę koncesji i pozwoleń, upraszczać przepisy gospodarcze, a także wprowadzać rozwiązania mające na celu zmniejszenie wpływu decyzji urzędowych i administracyjnych na funkcjonowanie podmiotów gospodarczych.

Jak wynika $z$ badań Instytutu Prognoz i Analiz Gospodarczych (2018), istotnym elementem walki z szarą strefą jest także promowanie i wspieranie rozwoju obrotu bezgotówkowego. Gotówka jest łatwa w użyciu i anonimowa, a płatności w szarej strefie są bowiem realizowane niemal wyłącznie w postaci gotówkowej tak, aby nie pozostawały żadne ślady transakcji. Działania wspierające obrót bezgotówkowy ze strony państwa to przykła- dowo wprowadzenie możliwości płacenia kartami w urzędach (Program Wsparcia Obrotu Bezgotówkowego), co z pewnością może przekonać wielu konsumentów do tego, że płatności kartami są wygodne i bezpieczne.

\subsection{Promowanie obrotu bezgotówkowego jako jedna z metod walki z szarą strefą}

Badania dotyczące szarej strefy, które były prowadzone przez Instytut Badań nad Gospodarka Rynkową (2016, s. 15), pokazują, że na świecie $z$ powodzeniem stosowane są różne metody promowania płatności elektronicznych.

W Wielkiej Brytanii instytucje państwowe zapoczątkowały płatności elektroniczne i zaczęły przyjmować je, np. w zakresie wynagrodzeń pracowników, płatności podatkowych czy też kar i grzywien.

We Włoszech wprowadzono obowiązek dokonywania płatności o wartości powyżej 1 tys. EUR drogą elektroniczną. Ustanowiono również ulgi podatkowe dla płatności bezgotówkowych w punktach handlowo-usługowych, połączone $z$ karami dla handlowców, którym udowodniono trzykrotne niewydanie klientom potwierdzenia zakupu w okresie 5 lat. Według badań, dodatkowe wpływy podatkowe z tego tytułu wyniosły 9,1 mld EUR.

Podobne wymogi wprowadzono w Hiszpanii (dla płatności powyżej 2,5 tys. EUR) i w Grecji (dla płatności powyżej 1,5 tys. EUR). Nałożono na banki obowiązek zgłaszania fiskusowi transakcji dokonywanych w punktach handlowo-usługowych.

W Meksyku władze wprowadziły specjalny fundusz wspomagający właścicieli małych sklepów w zakupie terminali płatniczych. W efekcie, nasycenie terminalami płatniczymi wzrosło o 200\%, a liczba transakcji dokonywanych kartami w placówkach handlowo-usługowych wzrosła w ciągu 5 lat o ponad $300 \%$.

W Korei Południowej, która wprowadziła już wiele działań promujących płatności bezgotówkowe (np. obowiązek instalacji terminala płatniczego w sklepach, których obrót roczny przekracza równowartość 20 tys. EUR), udział płatności kartami klientów in- 
dywidualnych zwiększył się z niecałych 5\% na początku lat 90. do ponad 50\% w 2009 roku. Co więcej, w Korei Południowej nie tylko sprzedawca uzyskuje odpis w podatku VAT, jeśli stosuje płatności elektroniczne, ale również obywatel zyskuje jednorazowy odpis pod warunkiem, że wydatki pokrywane za pomocą kart przekraczają 20\% jego dochodu dla kart kredytowych lub 25\% dla kart debetowych (Instytut Badań nad Gospodarką Rynkową, 2016, s. 16).

Przegląd literatury wskazuje na związek między obrotem bezgotówkowych a szarą strefą (Schneider, 2011).

Ważnymi narzędziami w walce o redukcję szarej strefy są rozpoczęte projekty $w$ ramach programu Od papierowej do cyfrowej Polski (Ministerstwo Cyfryzacji, 2017, s. 38), zainicjowanego przez Ministerstwo Rozwoju, Ministerstwo Finansów, Ministerstwo Cyfryzacji i Ministerstwo Zdrowia. Jednym $z$ nich jest projekt tzw. fiskalizacji online, czyli paragonów w chmurze obliczeniowej. Głównym celem tego typu systemów jest uzyskanie możliwości kontroli realizowanych transakcji przez aparat skarbowy w krótkim czasie od dokonania transakcji lub wręcz w cyklach dziennych. Ponadto, możliwe jest automatyczne przetwarzanie informacji o sprzedaży i typowanie podmiotów wykonujących podejrzane działania do kontroli. W niektórych rozwiązaniach, docelowo przewiduje się brak paragonów w wersji papierowej (Puls Biznesu, 2017). Systemy tego typu działają już m.in. w Turcji, Czechach, Chorwacji i na Węgrzech.

\section{Materiały i metody}

W niniejszym artykule zastosowano dwie metody badawcze: analizę danych wtórnych, a także krytyczny przegląd literatury. W tym celu, wykorzystano źródła polskie, jak i zagraniczne, dotyczące zjawiska szarej strefy. Szczegółową analizę przeprowadzono na materiałach F. Schneidera (2011, 2014), F. Schneidera i D. H. Enste (2000) oraz danych pochodzących z Instytutu Badań nad Gospodarką Rynkową (2016). Z uwagi na aktualność tematu, niniejsze opracowanie można potrak- tować jako preludium do pogłębionych badań, dotyczących ograniczania skali nierejestrowanych transakcji a także szerszego powiązania szarej strefy i obrotu bezgotówkowego.

\section{Wyniki badania}

$\mathrm{Na}$ podstawie krytycznej analizy literatury można uznać, że problem istnienia szarej strefy $\mathrm{w}$ gospodarce zarówno $\mathrm{w}$ Polsce, jak i w innych państwach europejskich, jest wciąż aktualny.

$Z$ pewnością bardzo istotne $w$ walce $z$ gospodarką nieobserwowalną są elementy profilaktyki, które powinny budować w świadomości społecznej przekonanie, że szara strefa jest zjawiskiem szkodliwym i w interesie społecznym leży jej ograniczanie. Warto też uświadamiać społeczeństwo, że dokonując zakupu towaru lub usługi w szarej strefie, działa się $\mathrm{w}$ efekcie na swoją niekorzyść, ponieważ uszczuplanie dochodów państwa przez szarą strefę powoduje w długim okresie konieczność podnoszenia podatków i prowadzi do wzrostu obciążeń fiskalnych dla wszystkich podatników. Warte wsparcia są więc wszelkie kampanie społeczne, które mają o tym przekonywać i zachęcać do płatności elektronicznych, np. stosowana $w$ wielu państwach, a w przeszłości także w Polsce, akcja pod hasłem Weź paragon! czy też popularne Loterie paragonowe. $Z$ kolei przykładem bardziej represyjnego rozwiązania, niekoniecznie rekomendowanego, może być Grecja, w której w 2012 roku wprowadzono przepisy, zgodnie z którymi klienci, którzy nie otrzymali paragonu fiskalnego w restauracjach, mieli prawo w ogóle nie płacić za posiłek (Instytut Badań nad Gospodarką Rynkową, 2016, s. 6).

\section{Zakończenie}

Zjawisko szarej strefy występuje we wszystkich gospodarkach państw europejskich i stanowi problem nie tylko dla budżetu państwa, ale także jedno $z$ największych zagrożeń dla legalnie działających przedsiębiorstw. Dla- 
tego też wiedza na jej temat jest niezwykle potrzebna.

Jednym $z$ kierunków polityki ograniczania szarej strefy, w zakresie rejestrowania transakcji, powinien być wzrost kontroli nad obiegiem pieniądza.

Wynika to z założeń, że o ile obrót gotówkowy nie jest rejestrowany $\mathrm{w}$ żadnych spójnych systemach elektronicznych, to obrót bezgotówkowy, w szczególności transakcji kartami, skutkuje automatyczną rejestracją płatności, które mogą być powiązane ze sprzedażą prowadzoną przez przedsiębiorstwo. Wskazuje to, że obrót bezgotówkowy służy wzrostowi kontroli przez państwo nad obiegiem pieniądza, wraz z zwiększaniem się jego zakresu razem $z$ transakcjami, które mogą być nierejestrowane. $Z$ drugiej strony, działalność różnych przedsiębiorstw w szarej strefie może blokować rozwój obrotu bezgotówkowego. Na podstawie przeprowadzonej analizy wskazano na konieczność kontynuowania badań $\mathrm{w}$ tym obszarze, uwzgledniających powiązania w dwóch kierunkach.

\section{Bibliografia}

Global Compact Network Poland. (2016). Przeciwdziatanie szarej strefie $w$ Polsce. Pobrane 15.06.2019 z https://ungc.org.pl.

Główny Urząd Statystyczny. (2019). Stownik pojęć. Pobrane 06.06.2019 z http://stat.gov.pl.

Gołębiewski, G. (2007). Zjawisko szarej strefy z uwzględnieniem gospodarki polskiej. Wspótczesna Ekonomia, 1(1).

Grant Thornton. (2016). Polska liderem produkcji prawa w Unii Europejskiej. Pobrane 05.05.2018 z https://grantthornton.pl.

Instytut Badań nad Gospodarką Rynkową. (2016). Szara strefa w polskiej gospodarce w 2016 roku. Pobrane 04.12.2018 z http://www.ibngr.pl.

Instytut Koniunktur i Cen Handlu Zagranicznego. (2005). Metodologia badań szarej strefy na rynku ustug turystycznych. Pobrane 01.02.2019 z https://www.msit.gov.pl.
Instytut Prognoz i Analiz Gospodarczych. (2018). Szara strefa 2018. Pobrane 02.04.2019 z http:// www.ipag.org.pl.

Janik, E. (2010). Szara strefa: patologia życia gospodarczego. Zeszyty Naukowe Uniwersytetu Rzeszowskiego. Seria Prawnicza. Prawo, 9.

Ministerstwo Cyfryzacji. (2017). Program „Od papierowej do cyfrowej Polski": ważniejsze informacje $i$ aktualny status prac. Pobrane 01.08.2017 z http://archiwum.mc.gov.pl.

Ministerstwo Pracy i Polityki Społecznej. (2008). Przyczyny pracy nierejestrowanej: jej skala, charakter $i$ skutki społeczne. Pobrane 01.08.2017 z https://www.mpips.gov.pl.

Najwyższa Izba Kontroli. (2017). NIKo ograniczaniu szarej strefy $w$ gospodarce. Pobrane 28.06.2017 $z$ https://www.nik.gov.pl.

Podatki.biz. (2017). Podatki 2017: wyższe kary za wytudzenia VAT już od 1 marca. Pobrane 10.08.2017 z https://www.podatki.biz.

Puls Biznesu. (2017). Nie takie straszne kasy on-line. Pobrane 21.03.2019 z https://www.pb.pl.

Schneider, F. (2011). The shadow economy in Europe: using electronic payment systems to combat the shadow economy. Pobrane 12.11.2018 $z$ http://feelingeurope.eu.

Schneider, F. (2014). The shadow economy and shadow labor force: a survey of recent developments. IZA Discussion Paper Series, 8278.

Schneider, F., i Enste, D.H. (2000). Shadow economies: size, causes, and consequences. Journal of Economic Literature, 38(1).

Topolewska, M. (2010). Polski system pomocy społecznej prowadzi do uzależnienia od zasitków. Pobrane 12.07.2019 z http://forsal.pl.

Ustawa z 10 lutego 2017 roku o zmianie ustawy Kodeks karny oraz niektórych innych ustaw (Dz.U. 2017 poz. 244).

Informacje uzupetniające

Wkład autorski: autor zaakceptował ostateczną wersję artykułu.

Źródła finansowania: artykuł został w całości sfinansowany ze środków własnych autora 
The shadow economy and methods of combating it in the scope of reducing the scale of unregistered transactions

\section{Abstract}

Motivation: The shadow economy is still an insufficiently researched problem that has a very large and negative impact on the functioning of the economy. It is a problem not only for the state budget, but also one of the activities for legally operating enterprises.

Aim: The main aim of the article is to identify the shadow economy, taking into account its development. The specific aim is to indicate the methods of combating the shadow economy in reducing the scale of unregistered transactions. Materials and methods: In the article the analysis of secondary sources as well as the literature on the subject was used.

Results: Based on the conducted analysis, it can be concluded that the problem of the existence of a shadow economy in the economy is still current. One of the methods of combating the shadow economy, especially in the area of unregistered transactions, are activities that promote the development of cashless transaction. Attention was also paid to the possibility of blocking the development of non-cash transactions by enterprises operating in the shadow economy. However, this problem requires in-depth, comprehensive research in the future.

Keywords: shadow economy; unregistered transactions; cashless transactions JEL: O17; E62; E42 